\title{
15. LATE PLIOCENE TO MID-PLEISTOCENE (2.6-1.0 M.Y.) CARBONATE DISSOLUTION IN THE WESTERN EQUATORIAL ATLANTIC: RESULTS OF LEG 154, CEARA RISE ${ }^{1}$
}

\author{
T. Bickert, ${ }^{2}$ R. Cordes, ${ }^{2}$ and G. Wefer ${ }^{2}$
}

\begin{abstract}
We present carbonate dissolution records (carbonate content, sand percentage, and foraminiferal fragmentation indices) for Sites 927 (3315 m water depth) and 929 (4356 m), which were recovered during Ocean Drilling Program Leg 154 at the northeast slope of the Ceara Rise, western equatorial Atlantic. These records comprise the time interval from 2.6 to $1.0 \mathrm{~m}$.y. Dating is based on tuning variations of the magnetic susceptibility records to orbital parameters.

Neogene sediments on the Ceara Rise consist primarily of biogenous carbonate ooze that is diluted by varying input of terrigenous material delivered by the nearby Amazon River. Similar to oxygen isotopic variations, the carbonate and sand content records are dominated by strong 41-k.y. cycles during the late Pliocene and the early Pleistocene, except for the period between 2.0 and 1.6 m.y., which shows predominantly precession-driven fluctuations. Higher mean carbonate and sand contents in both sites indicate a deeper lysocline and hence a better deep-water ventilation during this intermediate period. The intersite comparison of the accumulation rates shows that the lower sedimentation rates in the deeper Site 929 result exclusively from the lower carbonate accumulation due to dissolution. The accumulation rates of the terrigenous material are nearly identical over most of the record, which confirms the validity of the assumption that the sediment input for the two sites is exactly the same. Crossspectral analysis indicates that Pliocene-Pleistocene changes in carbonate dissolution and hence in deep-water production appear to lead ice volume at the obliquity band, but are in-phase at the precessional band. However, the similarity between the foraminiferal dissolution indices, which are independent of terrigenous dilution, and the carbonate and sand content records reveal that the decay of terrestrial organic matter, which reduces carbonate ion concentration in the pore water, is more important for carbonate dissolution at the shallower Site 927 than changes in deep-water chemistry. This observation supports the idea of the influence of even supralysoclinal dissolution to the ocean carbon budget.
\end{abstract}

\section{INTRODUCTION}

Deep-sea carbonate sediments cover about one-half of the total oceanic floor (Berger et al., 1976; Biscaye et al., 1976; Kolla et al., 1976) and act as a large and reactive reservoir for carbon dioxide (Broecker, 1982; Broecker and Peng, 1987; Sundquist and Broecker, 1985). Understanding temporal and spatial changes in carbonate preservation is of key importance for testing the numerous models that seek to explain past changes in atmospheric $\mathrm{pCO}_{2}$ through changes in the oceanic carbon cycle (Boyle, 1988; Broecker and Peng, 1989; Keir, 1990; Archer and Maier-Reimer, 1994).

Since the early work of Arrhenius (1952), it has been clearly established that carbonate contents of pelagic sediments show cyclic variations associated with Pleistocene glacial-interglacial changes (Berger, 1973; Volat et al., 1980; Moore et al., 1982; Crowley, 1985; Farell and Prell, 1989; Le and Shackleton, 1992; Howard and Prell, 1994). Whereas in the Atlantic and Southern Oceans dissolution generally is intensified during glacial periods (Gardner, 1975; Crowley, 1983; Balsam and McCoy, 1987; Howard and Prell 1994, Bickert and Wefer, 1996), the Pacific carbonate fluctuations are related to the rate of change in climate, with enhanced dissolution during the transition from interglacial to glacial times and increased preservation during deglaciation periods (Berger, 1973; Farell and Prell, 1989; Hebbeln et al., 1990; Wu et al., 1990; Zahn et al., 1991; Le and Shackleton, 1992; Yasuda et. al., 1993, Bickert et al., in press). This asymmetry between the Atlantic and the Pacific dissolution pattern has been attributed to changes in basin-to-basin fractionation resulting from

'Shackleton, N.J., Curry, W.B., Richter, C., and Bralower, T.J. (Eds.), 1997. Proc. ODP, Sci. Results, 154: College Station, TX (Ocean Drilling Program).

${ }^{2}$ Fachbereich Geowissenschaften, Universität Bremen, 28334 Bremen, Federal Republic of Germany. bickert@zfn.uni-bremen.de variations in North Atlantic Deep Water (NADW) formation (Berger, 1970; Volat et al., 1980; Crowley, 1985).

However, deep-water mass properties are not the only controlling factor for carbonate dissolution. Studies of Emerson and Bender (1981), and more recently, benthic flux chamber experiments investigated by Jahnke et al. (1994), showed that even in supralysoclinal waters, which are supersaturated with respect to calcite, sediments undergo a significant carbonate dissolution. They propose that this dissolution results from the decay of organic matter, reducing carbonate ion concentration in the pore water. Furthermore, long records of carbonate fluctuations exhibit long-term trends in dissolution (e.g., the mid-Brunhes dissolution cycle), which are thought to be associated with global changes in the carbon reservoir of the oceans (Vincent, 1981; Farell and Prell, 1991; Bassinot et al., 1994, Bickert et al., in press). Thus, for reconstructing the deep-water circulation in the past, both the respiratorical effect and the global trend have to be considered to extract the true water mass signal in dissolution records.

The Ceara Rise is an ideal place to observe changes in the depth distribution of deep-water properties of the Atlantic Ocean because it intersects these water masses over the depth range of 2800-4500 m. The Ceara Rise is an aseismic ridge in the western equatorial Atlantic bearing a thick cover of calcareous ooze with various amounts of terrigenous material delivered by the nearby Amazon River. Ocean Drilling Program (ODP) Sites $927\left(5^{\circ} 27.7^{\prime} \mathrm{N}, 44^{\circ} 28.8^{\prime} \mathrm{W}\right)$ and 929 $\left(5^{\circ} 58.6^{\prime} \mathrm{N}, 43^{\circ} 44.4^{\prime} \mathrm{W}\right)$, on which we report here, are drilled in a depth transect at depths of $3315 \mathrm{~m}$ and $4356 \mathrm{~m}$, respectively (Fig. 1). At shallower depths, the Ceara Rise is bathed in NADW (Reid, 1989), with a broad transition zone to Lower Circumpolar Deep Water (LCDW) below between 4200 and $4600 \mathrm{~m}$, in which the deeper site is located. The depth of lysocline today is about $4500 \mathrm{~m}$, just below the depth of Site 929 (Fig. 2). Because of the proximity of the two sites, by comparing only synchronous measurements, the vertical gradients in carbonate dissolution will be independent of global 


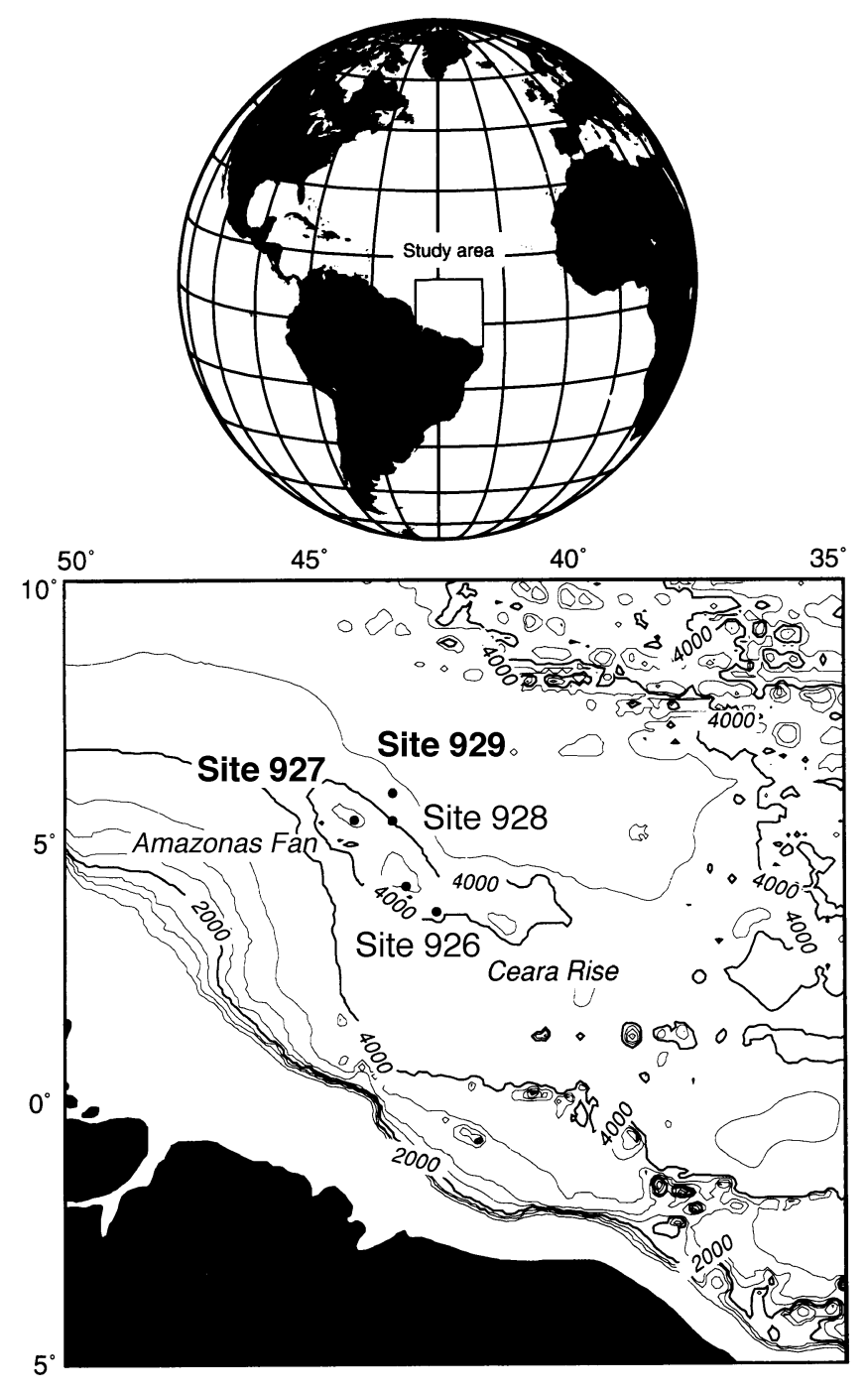

Figure 1. Location map showing the positions of the Sites 925 through 929, drilled during Leg 154 on Ceara Rise. Bold letters mark sites for which carbonate dissolution records are presented in this study.

changes in the ocean's carbonate concentration and must be related to changes in the properties of water masses or in their water column positions.

The purpose of this study is to present carbonate dissolution records (carbonate content, sand percentage, and foraminiferal fragmentation indices) from the deep western equatorial Atlantic Ocean to decipher the effects controlling the deep-water properties in the past and to reconstruct the deep-water circulation for the late Pliocene to mid-Pleistocene times (2.6-1.0 m.y.).

\section{MATERIAL AND METHODS}

The sand content (i.e., >63- $\mu \mathrm{m}$ fraction) of deep-sea carbonates decreases as dissolution progresses (Johnson et al., 1977; Berger et al., 1982; Wu et al., 1990). The reason is that foraminiferal shells are weakened by dissolution and tend to break down in small fragments. Subsequently, material moves from the coarse fraction into finer fractions. Inspection of other dissolution indices, such as whole-test index of planktonic foraminifers, fragmentation index on single species, and abundance ratios of species of contrasting solution susceptibilities, investigated by Hebbeln et al. (1990) and Yasuda et al.

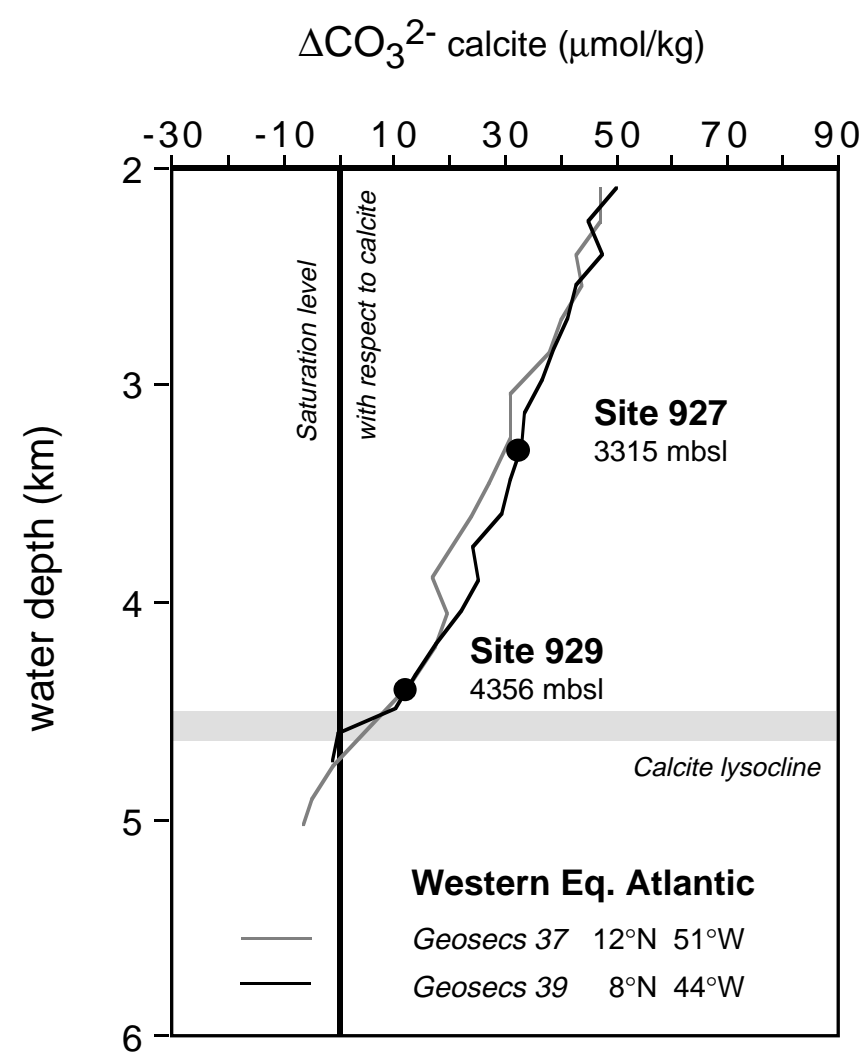

Figure 2. $\Delta \mathrm{CO}_{3}{ }^{2-}$ depth profiles of GEOSECS stations 37 and 39, which represent best the deep-water conditions at northeast Ceara Rise. The shaded areas mark the modern depth of lysocline with respect to calcite.

(1993) in sediments of the Ontong Java Plateau, showed a good agreement to the sand content records of each study. In addition, Peterson and Prell (1985) established in a depth transect study on the Ninetyeast Ridge that about $60 \%$ of the whole sand-sized planktonic foraminifers were already broken at the lysocline level, whereas no more than $20 \%-30 \%$ of carbonate was lost. Thus, a decrease in coarse fraction content is a much more sensitive indicator of increasing dissolution than is the carbonate content.

Sites 927 and 929 were sampled at $10-\mathrm{cm}$ intervals from 42.35 to 98.98 meters composite depth (mcd) and from 34.79 to $86.34 \mathrm{mcd}$, respectively, along the composite record for each site. Coarse fraction contents were obtained in all cores through wet-sieving of $8-\mathrm{cm}^{3}$ bulk sediment over a $63-\mu \mathrm{m}$ mesh sieve. Samples were then dried and weighed to determine the weight percent of sand-size particles. As a foraminiferal dissolution index, we examined the fragmentation of planktonic foraminifers in the subsieved 250 - to $425-\mu \mathrm{m}$ size fraction. Results are expressed as percentage of fragments to the sum of fragments and whole tests. A second index was obtained by determining the fragmentation of Pulleniatina obliquiloculata shells (355to $425-\mu \mathrm{m}$ fraction), which is known to be a dissolution-resistant planktonic species (Hebbeln et al., 1990).

For the determination of the dry bulk densities, which are necessary to calculate the accumulation rates of sediment components, about $2-\mathrm{cm}^{3}$ bulk sediment was weighed, freeze dried, and then weighed again. The dry bulk densities were calculated using the empiric equation of Ruddiman and Janecek (1989). The results match the shipboard measurements taken during Leg 154 (Curry, Shackleton, Richter, et al., 1995). Accumulation rates of single sediment components were determined by multiplying their percentage with dry bulk density and the sedimentation rates and are expressed in grams per square meter per year. 
The carbonate content of each sample was measured using a LECO-CS 244 element analyzer for total carbon (TC) measurements, which were converted to carbonate percentages by multiplying by 8.33. Because the amount of organic carbon in these sediments is always lower than $0.15 \%$ (Curry, Shackleton, Richter, et al., 1995), no correction for the TC has been done. The resulting maximal deviation of $1.25 \%$ in carbonate is close to the analytical precision of the instrument $( \pm 0.1 \%$ in TC, which is $\pm 0.83 \%$ in carbonate, P. Müller, pers. comm.) and well below the variability observed in the measured samples.

The epibenthic taxa Cibicidoides wuellerstorfi and Cibicides sp. were analyzed for stable carbon and oxygen isotopic composition using standard procedures (Bickert et al., Chapter 16, this volume). One to two specimens of this species were picked from the $>250-\mu \mathrm{m}$ size fraction. The samples were analyzed using a Finnigan MAT 252 micromass-spectrometer coupled with a Finnigan automated carbonate device at the University of Bremen. The carbonate was reacted with orthophosphoric acid at $75^{\circ} \mathrm{C}$. The reproducibility of the measurements, as referred to an internal carbonate standard (Solnhofen limestone), is $\pm 0.07 \%$ ond $\pm 0.05 \%$ o ( $1 \sigma$ over a 1 -yr period) for oxygen and carbon isotopes, respectively. The conversion to the Peedee belemnite (PDB) scale was performed using the international standards NBS 18, 19, and 20.

The dating of the two sites is based on tuning variations of the magnetic susceptibility records to orbital parameters using the 1,1 solution of Laskar (Bickert et al., Chapter 16, this volume). Sedimentation rates were calculated linearly between the obtained age control points. Due to the fact that the same datums were used at both sites, the sedimentation rates are comparable with each other without any conversion. According to a 10-cm-space sampling of both sites, the time resolution is about 2.8 k.y. for Site 927 and 3.3 k.y. for Site 929.

All data sets used in this study are available via the internet from the first author upon request.

\section{RESULTS}

Figure 3 illustrates the benthic oxygen isotope records measured on Cibicides wuellerstorfi and Cibicides sp. (Bickert et al., this volume), the carbonate contents, and the sand percentages of the carbonate of Sites 927 and 929 for the late Pliocene to mid-Pleistocene (2.6$1.0 \mathrm{~m} . y$.) time interval. The $\delta^{18} \mathrm{O}$ records exhibit the typical glacialinterglacial changes documenting the waxing and waning of the northern hemisphere ice sheets. As is known from many other sites, the cyclicity is dominated by an obliquity-related response for the late Pliocene and early Pleistocene times. The two records match each other well, confirming the validity of the age models obtained by tuning the susceptibility records to orbital parameters.

The sand percentage, as well as the carbonate content records, exhibit glacial-interglacial changes closely related to the oxygen isotope variability. Sand and carbonate contents were lower at times of ice maxima and higher during warm ages. However, the amplitude of the glacial-interglacial variations at the two sites was generally larger during the intervals from 2.6 to $2.0 \mathrm{~m}$.y. and from 1.6 to $1.0 \mathrm{~m}$.y. than in the intermediate interval. While most of the sand and carbonate content variations occurred at the obliquity frequency band, there was a switch to a precessional response between 2.0 and 1.6 m.y., especially in the shallower Site 927, which is documented in the power spectra presented in Figure 4. The weak response to obliquity is coincident with a smaller amplitude of this orbital parameter during this time interval (Fig. 3) but disagrees with the spectral pattern of the $\delta^{18} \mathrm{O}$ records, which show a high power at the 41-k.y. band for the two sites during all three time-intervals (Fig. 4). This observation implies that glacial-interglacial variations in carbonate deposition during the late Pliocene and early Pleistocene cannot be easily explained by icesheet forcing.
Site-by-site correlation between the two sites revealed that the sand and carbonate content records of the deeper Site 929 (4356 m) exhibit generally larger amplitudes than those of the shallower Site 927 (3315 m). The interglacial values of Site 929 were thereby close to those of Site 927 , but they were mostly lower by up to $5 \%$ in each parameter, exhibiting the modern depth gradient in carbonate ion concentration at the position of Ceara Rise, where both sites are located above the calcite lysocline, but with Site 929 closer to the lysocline than Site 927 (Fig. 2). On the other hand, the glacial values of the deeper site were much lower than those of the shallower site, indicating an increasing depth gradient in dissolution during cold stages. This was especially true for the early Pleistocene interval between 1.6 and 1.0 m.y., where the glacial values were close to zero in both the carbonate and the sand-vs.-carbonate contents, indicating the shoaling of the carbonate compensation depth (CCD) to the depth of Site 929. During glaciations in the interval between 2.0 and 1.6 m.y., higher mean carbonate and sand contents, especially in the deeper Site 929, indicate a deeper lysocline and hence better carbonate preservation during this intermediate period.

\section{DISCUSSION}

\section{Dissolution, Dilution, or Productivity?}

For interpreting carbonate deposition in a sediment sequence, the influences of changes in productivity of the surface waters, the dissolution due to deep-water corrosiveness, and the dilution by other sediment components must be evaluated in their relative importance in contributing to the variations in the concentration and accumulation of carbonate.

The sediment cover on Ceara Rise consists of only two components: (1) biogenic carbonate ooze, composed of nannofossil and foraminiferal shells, and (2) various amounts of terrigenous material, delivered by the nearby Amazon River. The noncarbonate particles are silt- to clay-sized. Neither sand-sized quartz grains or rock fragments nor opal skeletons of radiolarians have been observed in considerable amounts in the studied site sections (Curry, Shackleton, Richter, et al., 1995). Therefore, the coarse fraction of these sediments consists almost exclusively of sand-sized foraminifers. To evaluate the sand percentages as a recorder of carbonate dissolution, we investigated two foraminiferal preservation indices for the time interval between 1.5 and 2.0 m.y. in both sites. In contrast to the carbonate content and the sand percentages, these indices as well as the sand contents divided by the carbonate percentages should be independent of any dilution by other fine-grained, nonbiogenic particles.

Figure 5 illustrates the positive relationship between fine fraction/ carbonate contents (which is $100 \%$ minus sand/carbonate percentage) and foraminiferal preservation, thus arguing for a general control by carbonate dissolution. The much higher variability in both the fine fraction/carbonate and the foraminiferal fragment percentage records confirm the deeper Site 929 to be more affected by dissolution than the shallower Site 927. Therefore, the glacial values were much higher in Site 929 than they were in Site 927. The interglacial values were similar in the two sites, indicating low gradients in dissolution during warm stages but higher gradients during cold stages. This result is consistent with the dissolution pattern described from other studies in the Atlantic and Southern Oceans for the late Pleistocene (Gardner, 1975; Crowley, 1983; Balsam and McCoy, 1987; Curry and Lohmann, 1990; Howard and Prell, 1994, Verardo and McIntyre, 1994; Bickert and Wefer, 1996), and it is explained by the varying production of NADW and the subsequent volumetric increase of southern water masses as proposed by many authors (Curry et al., 1988; Duplessy et al., 1988; Oppo et al., 1990; Raymo et al., 1990; Sarnthein et al., 1994; Bickert and Wefer, 1996; Curry, 1996). It is also consistent with the pattern of benthic carbon isotopes measured in Sites 927 and 929, which gives evidence for an upward and 

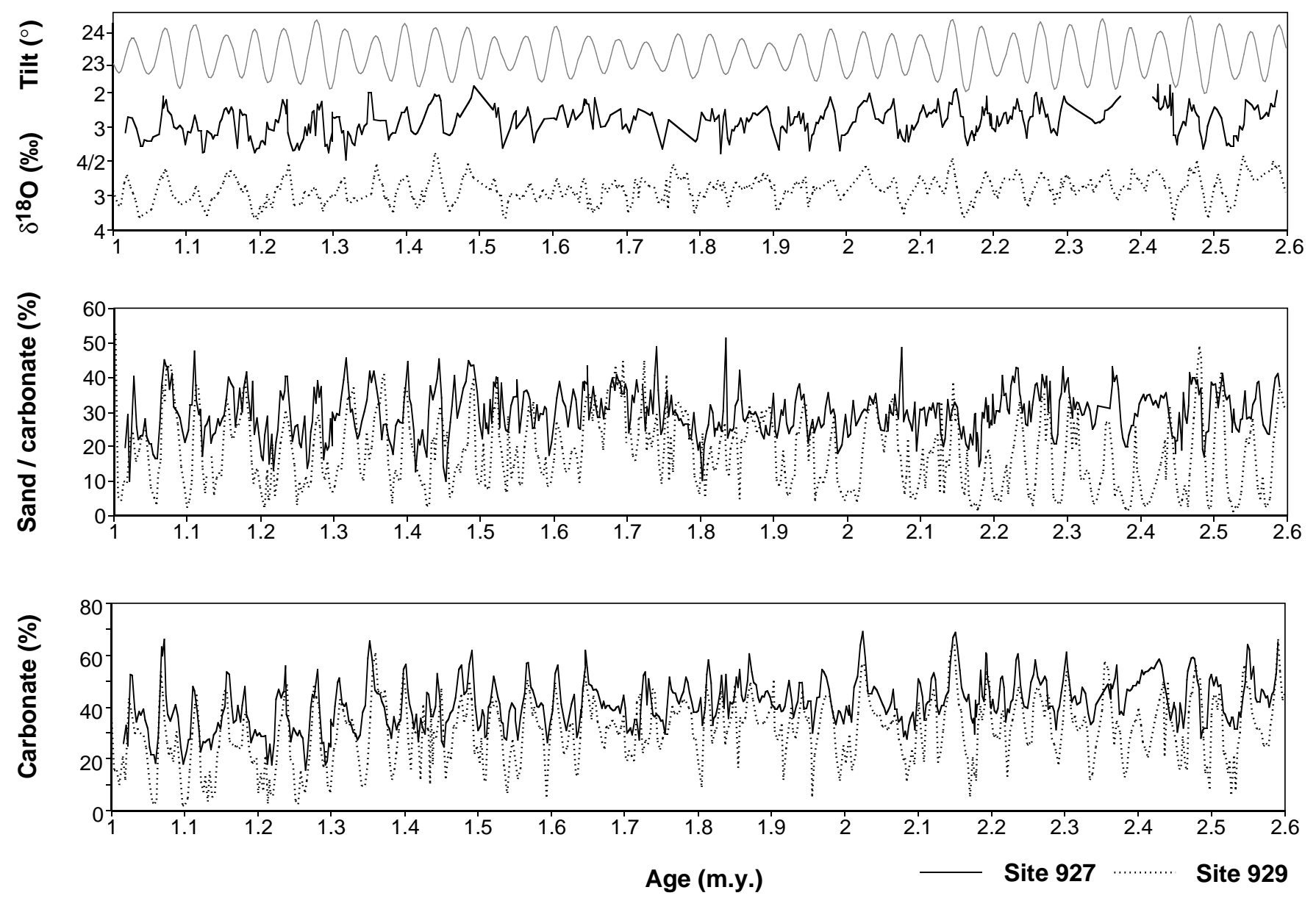

Figure 3. Records of benthic $\delta^{18} \mathrm{O}$, as compared with the earth obliquity, sand-over-carbonate percentages, and carbonate contents of Sites 927 and 929 vs. age.

Figure 4. Evolutionary power spectra comparing the $\delta^{18} \mathrm{O}$ and sand/carbonate records of Sites 927 and 929 from 1.1 to 2.6 m.y. in 0.5-m.y. windows. Spectral density is given in arbitrary units.
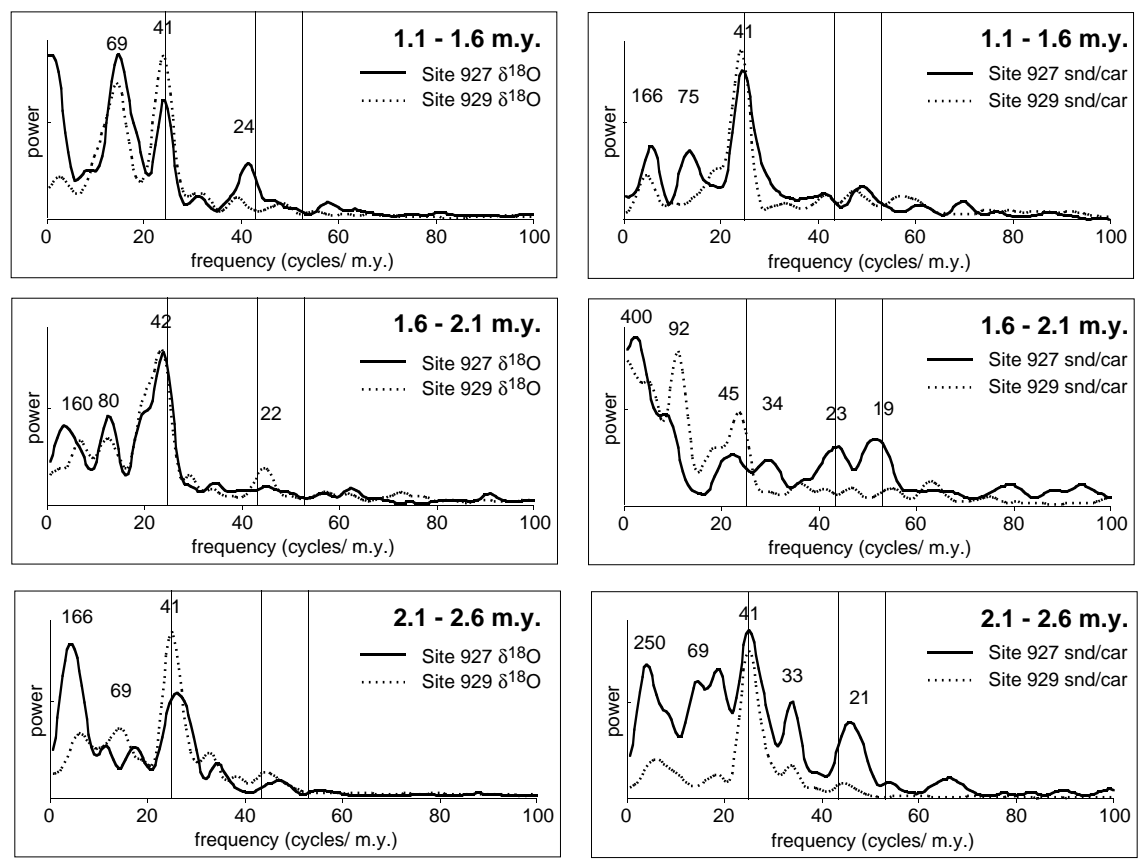

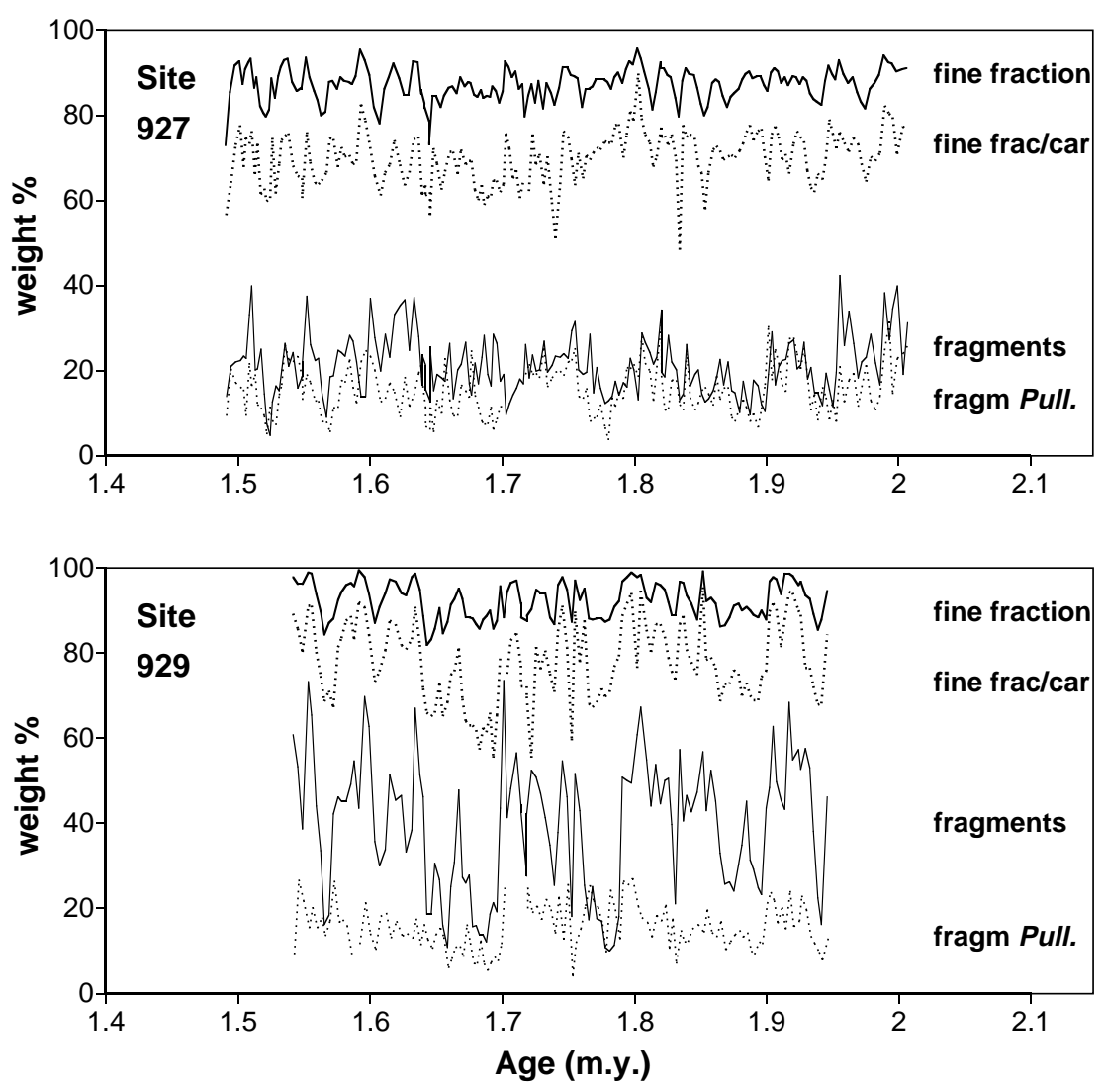

Figure 5. Comparison of different carbonate dissolution indices of Sites 927 and 929 during the interval between 1.5 and $2.0 \mathrm{~m}$.y. The indices are content of fine fraction $(<63 \mu \mathrm{m})$, fine fraction/carbonate, total percentage of foraminiferal fragments (counted in the 250- to $425-\mu \mathrm{m}$ size fraction), and percentage of fragments of the dissolution-resistant planktonic foraminifer species Pulleniatina obliquiloculata (counted in the 355 - to $425-\mu \mathrm{m}$ size fraction). downward movement of the mixing zone between the northern and southern component water masses (Bickert et al., this volume). Although the transition zone between NADW and LCDW always remained below the water depth of Site 929 (i.e., $4356 \mathrm{~m}$ ) during interglacials, the mean depth of the mixing zone varied with time during cold stages. Between 2.6 and 2.0 m.y., the transition zone lay at about $4000 \mathrm{~m}$, then deepened to about $4300 \mathrm{~m}$ with a short uplift event at 1.75 m.y. Since 1.6 m.y., the mixing zone rose again to its late Pleistocene level of about $3500 \mathrm{~m}$ (and shallower for some intervals).

On the other hand, Curry and Lohmann (1990) and Bickert and Wefer (1996) found that the lysocline in the deep equatorial Atlantic never rose to shallower than about 3700 to $3800 \mathrm{~m}$ during late Pleistocene glaciations. The reason for this upper depth limit is that carbonate dissolution is not only controlled by deep-water corrosiveness, but also a function of pressure (i.e., depth; Broecker and Peng, 1989). Therefore, the carbonate dissolution records of the shallow Site 927 (3315 m) should not have been influenced by dissolution. Surprisingly, there is a distinct dissolution variability recorded by all three parameters of Site 927. Although all of these parameters are independent of dilution by terrigenous material, there is a strong relationship between the fine fraction/carbonate and the total fine fraction records. Such a pattern reveals that the input of terrigenous material indirectly influences the local conditions for carbonate preservation at the mid-depth Ceara Rise. A possible explanation might be a dissolution effect due to the respiration of terrestrial organic matter. Studies of Emerson and Bender (1981), and more recently, benthic flux chamber experiments investigated by Jahnke et al. (1994), showed that, even in supralysoclinal waters that are supersaturated with respect to calcite, sediments undergo a significant carbonate dissolution. It is proposed that this dissolution results from the decay of organic matter, reducing carbonate ion concentration in the pore water. As is known from surface sediment studies of the Amazon Fan, a high amount of organic material is delivered by the Amazon River together with the terrigenous inorganic particles, which leads to organic carbon contents of about $1.0 \%$ in these sediments (Damuth and Kumar, 1975; Damuth, 1977; Richey et al., 1980). On the other hand, the total organic carbon (TOC) contents on Ceara Rise sediments at these depths varied between $0.2 \%$ and $0.4 \%$ during the late Pleistocene, indicating twice the contents expected for a low productive marine environment (Curry and Lohmann, 1990; Rühlemann et al., 1996). The high amount of terrigenous material might be responsible for the higher TOC contents at Ceara Rise. Recent analyses of carbon isotopes in organic matter of two gravity cores from Ceara Rise (GeoB 1515, 1523) from about $3000 \mathrm{~m}$ water depth indicate that up to $40 \%$ of the TOC is of terrestrial origin. The marine residual of TOC then varies between $0.1 \%$ and $0.25 \%$, which is known to be typical for other low productive areas (Bickert, 1992). Therefore, we propose the respiration of additional terrigenous organic matter as a possible explanation for the supralysoclinal dissolution pattern in Site 927.

However, the differences in detail between the fine fraction/carbonate and the foraminiferal indices reveal that other factors need to be included, such as past changes in the mean size of foraminifer shells or changes in the nannofossil to foraminifer ratio (Briggs et al., 1985; Mienert and Bloemendal, 1989). The differences between the average percentage of fine fraction/carbonate (about 70\%) and of foraminifer fragments (about $15 \%$ for Pulleniatina fragments and $20 \%$ for total fragments) reveal that more than two-thirds of the carbonate fine fraction consists of nannofossil placoliths. The nannofossil to foraminifer ratio of 2:1 also explains that the amplitude of the foraminiferal fragmentation index (all species) in both sites is about twice of that of the sand/carbonate index.

Why are the amplitudes of the Pulleniatina fragmentation index similar in the two sites? The preservation index using the shells of the planktonic foraminifer taxon Pulleniatina obliquiloculata, which is known to be a dissolution-resistant species (Hebbeln et al., 1990; Yasuda et al., 1993), was investigated in the relatively large size fraction between 355 and $425 \mu \mathrm{m}$. The abundance distribution of different 
size classes in the Indian Ocean Core MD900938 (Bassinot et al., 1994) confirm that changes in grain-size composition mainly result from variations in the relative importance of the coarse end-member $>355 \mu \mathrm{m}$. Because Pulleniatina shell sizes are close to this size fraction, the number of fragments of the intermediate-size fractions $<355$ $\mu \mathrm{m}$ increases with increasing dissolution, while the fragment-towhole-test ratio in the fraction $>355 \mu \mathrm{m}$ does not change much. Therefore, the variability of this index is as low in the deeper Site 929 as in the shallower Site 927.

\section{Accumulation Rates}

To evaluate the loss of carbonate with increasing dissolution at the Ceara Rise, we calculated the accumulation rates for carbonate and terrigenous material for Sites 927 and 929 (Fig. 6). Due to the lack of significant amounts of opal in Pliocene and Pleistocene sediments at Ceara Rise (Curry, Shackleton, Richter, et al., 1995), the content of terrigenous material was defined as the difference between $100 \%$ and the carbonate content. The sedimentation rates of the two sites were coherent to a high degree, indicating the regularity of the sediment cover on the northeast-slope of the Ceara Rise. Over most of the record, the sedimentation rates of Site 929 were lower by $15 \%$ as compared with the rates of Site 927. There was a slight decrease in sedimentation rates at both sites toward the Pleistocene (on the order of $4 \mathrm{~m} / \mathrm{m} . \mathrm{y}$.) between 2.6 and $1.0 \mathrm{~m} . \mathrm{y}$.

The intersite comparison of the accumulation rates showed that the lower sedimentation rates in the deeper Site 929 result exclusively from the lower carbonate accumulation. The accumulation rates of the terrigenous material were nearly identical over most of the record, which confirms the validity of the assumption that the sediment input for the two sites is exactly the same. Although slightly higher terrig- enous accumulation rates, especially since 1.35 m.y., might be explained by downslope transport of marine sediments from shallower to deeper regions, visual inspection of the cores revealed neither turbidites nor winnowed deposits. Analysis of the bathymetry of the seafloor surrounding the site positions revealed gradients with slopes close to $1.5^{\circ}$, which is usually too low to induce downslope transport. Therefore, redistribution is not a viable mechanism to explain the variations in the Ceara Rise time series. Instead, the variability in the accumulation of terrigenous material is believed to be controlled by the surface ocean circulation (Damuth and Kumar, 1975; Damuth, 1977). Today, the North Brazil Current distributes sediments from the Amazon River discharge to the northwest, bypassing the sites of the Ceara Rise. During glacials, the along-shore current was weakened, which allowed the suspended matter to prograde in the open ocean. Another control mechanism for the terrigenous input on the Ceara Rise might be the intensity of the deep western boundary current, which is also known to vary in connection with climatic changes (Curry et al., 1988; Duplessy et al., 1988; Oppo et al., 1990; Raymo et al., 1990; Sarnthein et al., 1994; Bickert and Wefer, 1996; Curry, 1996). Both mechanisms explain the dominance of the obliquity cycle observed in the dissolution records because of their link to the growth and decay of Northern Hemisphere ice sheets.

The accumulation rates of carbonate mostly ranged between 5 and $25 \mathrm{~g} / \mathrm{m}^{2} / \mathrm{yr}$ for Site 927 and between 0 and $20 \mathrm{~g} / \mathrm{m}^{2} / \mathrm{yr}$ for Site 929 , respectively (Fig. 6). The carbonate accumulation was therefore generally lower than the accumulation of terrigenous material. Although the terrigenous rates exhibited constant mean values throughout the entire interval studied here, there was a decrease in the carbonate accumulation especially since 2.0 m.y. at both sites, accompanied by a decrease in the variability until $1.6 \mathrm{~m} . \mathrm{y}$. and then an increase toward the mid-Pleistocene. To balance the loss in carbonate between the
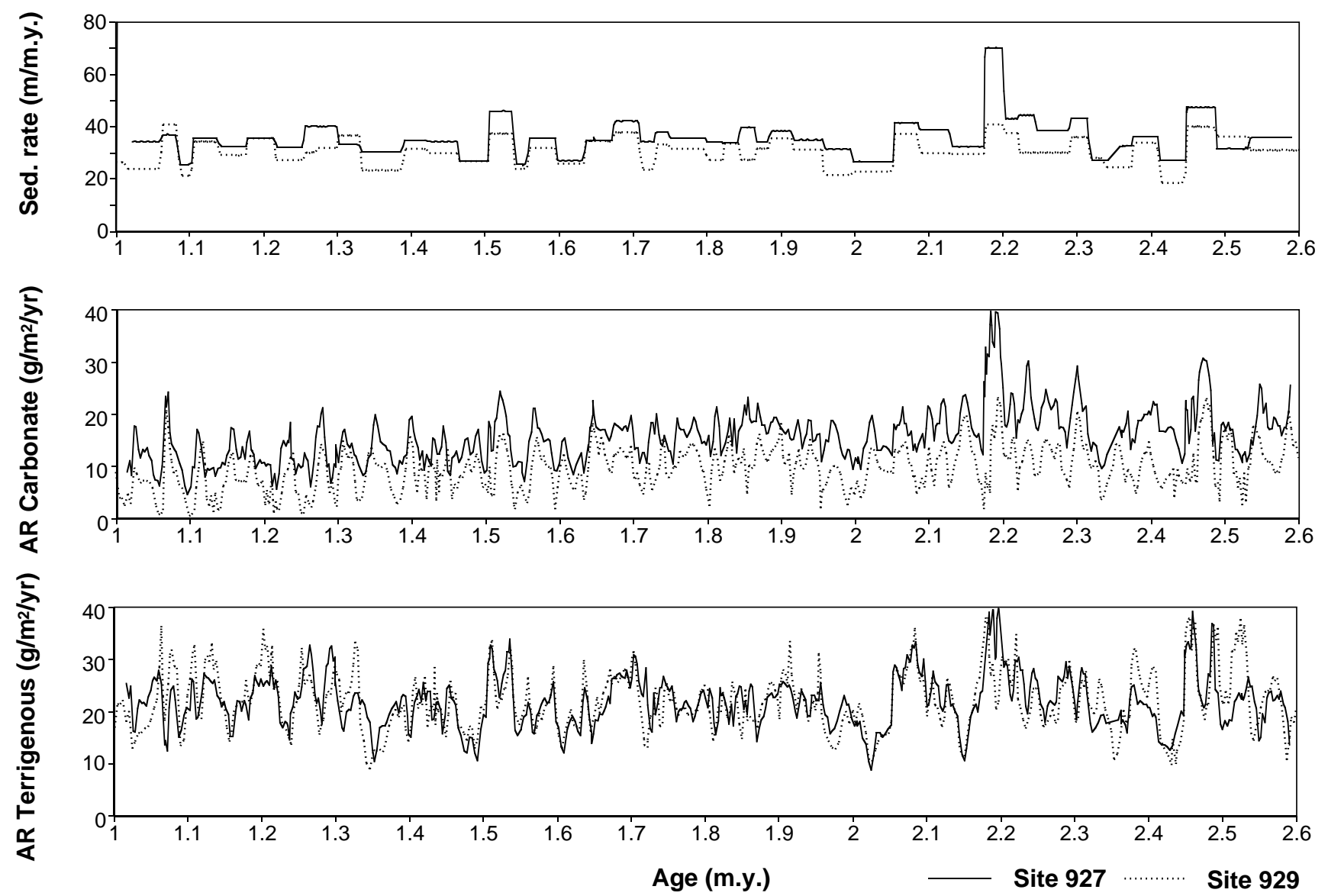

Figure 6. Records of sedimentation rates and carbonate and terrigenous accumulation rates of Sites 927 and 929 vs. age. 
shallower and the deeper site on Ceara Rise, we calculated the difference of Site 927 minus Site 929 carbonate accumulation and their ratio, expressed as percent carbonate accumulation of Site 927. Prior to these calculations, we linearly interpolated each record in 3-k.y. intervals and smoothed the resulting records to avoid artificially highfrequency noise while correlating.

Figure 7 illustrates a pretty constant loss of carbonate at the position of the deep Site 929 relative to the shallow Site 927 . The differences in the carbonate accumulation rates were about $5 \mathrm{~g} / \mathrm{m}^{2} / \mathrm{yr}$, slightly increasing toward the older part of the records. The shortterm variability of the differences might result from misalignments between the two accumulation records due to slight differences in the age models, which lead to maximal or minimal differences at deglaciations or inglaciations, rather than from real varying distances between contemporaneous values.

The ratios of the carbonate accumulations rates of Site 929 relative to those of Site 927 exhibit glacial-interglacial changes that were closely related to the oxygen isotope variability. The ratios were lower at times of ice maxima and higher during warm ages. However, the amplitude of the glacial-interglacial variations was generally smaller during the interval between 2.6 and 1.6 m.y. than in the younger interval between 1.6 and 1.0 m.y. During the Pliocene, about $10 \%-$ $30 \%$ of the carbonate accumulating at the shallower Site 927 were lost in the deeper Site 929 during interglacials, while about $60 \%$ were lost during glaciations. Slightly higher ratios between 2.0 and 1.6 m.y. indicate a smaller gradient in carbonate dissolution between the two sites. In the early Pleistocene, there was an increase in the amplitude of the ratios, indicating a smaller loss of carbonate $(0 \%-20 \%)$ and hence a better preservation during interglacials, but an increasing loss of carbonate during glaciations up to $100 \%$ in the last two glacial stages presented in Figure 7 (at 1.1 and 1.06 m.y.), indicating that the carbonate compensation depth rose to the level of Site 929 water depth (4356 m).

\section{Orbital Response of Carbonate Deposition}

Our comparison of carbonate dissolution records and oxygen isotopes has shown that the carbonate deposition variability was closely related to climate changes and occurred at the primary Milankovitch frequencies. However, spectral analyses of both oxygen isotope and carbonate dissolution records indicated that during the late Pliocene and early Pleistocene, glacial-interglacial variations in carbonate deposition cannot be easily explained by ice-sheet forcing. Crossspectral analyses between carbonate depositional parameters and ice volume (expressed in benthic oxygen isotopes) were investigated to evaluate the phasing between carbonate deposition and earth climate.

Table 1 gives the coherences and phase relations (expressed in radians and k.y.) of different carbonate depositional parameters vs. benthic oxygen isotopes for the obliquity and precession frequency bands. We analyzed the variability in the frequency domain using the Blackman-Tuckey approach with 33\% lags and the $80 \%$-confidence level $(\mathrm{k}=0.49)$. Changes in carbonate content, sand/carbonate percentages, and carbonate and terrigenous accumulation rates (the latter one given in reversed values, i.e., with a phase shift of $-\pi$, due to the inverse relation to all other parameters) show a strong, statistically significant response to climate forcing at the obliquity band but weaker response at the precessional band. All parameters show a lead of 2.5-4.1 k.y. in Site 927 and 4.1-5.8 k.y. in Site 929 at the 41-k.y. period, indicating a faster response of the carbonate deposition to orbital response compared to that of ice volume. Phase lags of 0.4-1.1 k.y. in Site 927 and phase leads of 0.46-1.7 k.y. in Site 929 at the 23k.y. period, however, are well within the time resolution due to sample spacing in both sites and therefore give no significant phase difference at the precessional band. The check with the cross spectra of the oxygen isotope records of the two sites exhibits the phasing between the two sites to be smaller than 0.39 k.y. at the obliquity and $0.26 \mathrm{k} . \mathrm{y}$. at the precessional band.

Our finding that carbonate deposition led ice volume at the obliquity band and was in phase at the precession band is consistent with earlier results of Howard and Prell (1994), who investigated carbonate dissolution records of Southern Ocean cores for the late Pleistocene (5.5 k.y. at the 41-k.y. band, and -0.4 k.y. at the 23-k.y. band for composite preservation index vs. SPECMAP stack). The slightly earlier response of the deeper site records as compared with the shallower site records also confirms the results of the depth-dependent spectra of equatorial Atlantic cores by Verardo and McIntyre (1994). Finally, our findings support the recent results of Curry (1996), who found that the Atlantic/Pacific-carbon isotope gradients of at least the

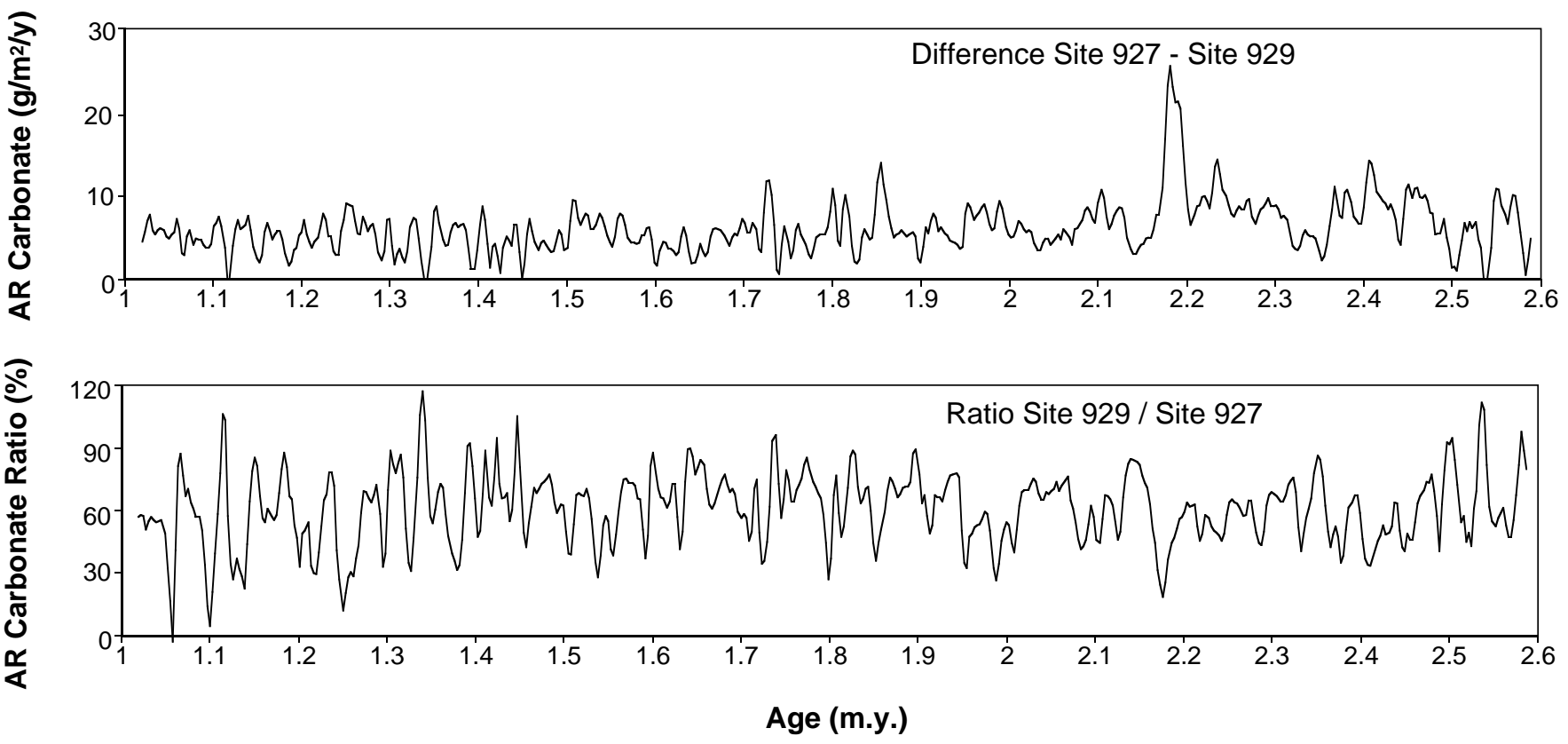

Figure 7. Differences (Site 927 minus Site 929) and ratios (Site 929/Site 927 in percent) of the carbonate accumulation rates vs. age. Prior to these calculations, the records have been linearly interpolated (3-k.y. intervals) and smoothed with a five-point running average. 
Table 1. Coherencies (coh) and phase relations ( $\phi$, expressed in radians and k.y.) of different carbonate depositional parameters vs. benthic oxygen isotopes for the obliquity and precession frequency bands.

\begin{tabular}{|c|c|c|c|c|c|c|}
\hline \multirow[b]{2}{*}{ Site and record vs. benthic $\delta^{18} \mathrm{O}$} & \multicolumn{3}{|c|}{41 k.y. } & \multicolumn{3}{|c|}{23 k.y. } \\
\hline & $\mathrm{coh}$ & $\phi(\mathrm{rad})$ & $\phi(\mathrm{k} . \mathrm{y})$. & coh & $\phi(\mathrm{rad})$ & $\phi$ (k.y.) \\
\hline 927 carbonate $\%$ & 0.92 & 0.54 & 3.53 & 0.58 & -0.11 & -0.40 \\
\hline 927 sand/carbonate $\%$ & 0.84 & 0.52 & 3.40 & $(0.48)$ & -0.51 & -3.33 \\
\hline 927 carbonate accumulation rate & 0.97 & 0.64 & 4.18 & $(0.46)$ & -0.36 & 2.35 \\
\hline 927 terrigenous accumulation rate & 0.76 & 0.39 & 2.55 & 0.52 & -0.22 & -0.81 \\
\hline 929 carbonate $\%$ & 0.93 & 0.72 & 4.64 & 0.67 & 0.07 & 0.46 \\
\hline 929 sand/carbonate & 0.93 & 0.89 & 5.81 & $(0.35)$ & 0.30 & 1.96 \\
\hline 929 carbonate accumulation rate & 0.97 & 0.74 & 4.83 & 0.72 & 0.17 & 1.11 \\
\hline 929 terrigenous accumulation rate & 0.93 & 0.64 & 4.18 & $(0.44)$ & 0.26 & 1.70 \\
\hline 927 vs. 929 benthic $\delta^{18} \mathrm{O}$ & 0.94 & 0.06 & 0.39 & 0.66 & -0.04 & -0.26 \\
\hline
\end{tabular}

Notes: We analyzed the variability in the frequency domain using the Blackman-Tuckey approach with $33 \%$ lags and at the $80 \%$-confidence level $(\mathrm{k}=0.49)$. Parentheses highlight coherencies below the $80 \%$-confidence level.

deeper cores on Ceara Rise led the ice volume during the late Pleistocene at the obliquity band.

The early response of deep-water production is congruent to the four-stage model proposed by Imbrie et al. (1992) on the basis of observed phase relationships between ice volume and several deepwater proxies. The model suggests that the lower branch of NADW plays a significant role in the transfer of heat between the Northern and Southern Hemispheres. The depth-related difference in the phasing of ice volume and deep-water production supports the observations by Imbrie et al. (1992) at least for the obliquity periods of climate change.

\section{CONCLUSIONS}

Carbonate dissolution data (carbonate content, sand percentage, and foraminiferal fragmentation) from ODP Sites 927 (3315 m) and $929(4356 \mathrm{~m})$ were used to reconstruct the history of deep-water chemistry and circulation in the western Atlantic for the late Pliocene and early Pleistocene times (2.6-1.0 m.y.). Dating is based on tuning variations of the magnetic susceptibility records to orbital parameters. According to a 10 -cm-space sampling, the time resolution is about 2.8 k.y. in Site 927 and 3.3 k.y. in Site 929.

Neogene sediments on Ceara Rise consist primarily of biogenic carbonate ooze, that is diluted by varying input of terrigenous material, delivered by the nearby Amazon River. Similar to oxygen isotopic variations, the carbonate and sand content records were dominated by strong 41-k.y. cycles during the late Pliocene and the early Pleistocene, except for the period between 2.0 and 1.6 m.y., which shows predominantly precession-driven fluctuations. Higher mean carbonate and sand contents, especially in the deeper Site 929, indicate a deeper lysocline and hence a better deep-water ventilation during this intermediate period. Cross-spectral analysis indicates that Pliocene-Pleistocene changes in carbonate dissolution and hence in deep-water production appear to lead ice volume at the obliquity band by about 3-5 k.y., but are in phase at the precessional band, providing partial confirmation of the Imbrie et al. (1992) model of a deep-water-climate link. However, the similarity between the foraminiferal dissolution indices, which are independent of terrigenous dilution, and the carbonate and sand content records reveal that the decay of terrestrial organic matter, which reduces carbonate ion concentration in the pore water, is more important for carbonate dissolution at the shallower Site 927 than changes in deep-water chemistry. This observation supports the idea of Archer and Mayer-Reimer (1994) of the influence of even supralysoclinal dissolution to the ocean carbon budget.

\section{ACKNOWLEDGMENTS}

We thank the crew and scientific party of Leg 154 for a successful venture at sea and ODP for providing samples. We are indebted to Peter Müller, who carefully supervises the operation of the LECO element analyzer of the Fachbereich Geowissenschaften, University of Bremen. We would like to thank the reviewers of this manuscript. We acknowledge financial support from the Deutsche Forschungsgemeinschaft (We 992/18).

\section{REFERENCES}

Archer, D., and Maier-Reimer, E., 1994. Effect of deep-sea sedimentary calcite preservation on atmospheric $\mathrm{CO}_{2}$ concentration. Nature, 367:260263.

Arrhenius, G.O.S., 1952. Sediment cores from the east Pacific. Reports of the Swedish Deep Sea Expedition, 1947-1948, 5:1-202.

Balsam, W.L., and McCoy, F.W.J., 1987. Atlantic sediments: glacial/interglacial comparisons. Paleoceanography, 2:531-542.

Bassinot, F.C., Beaufort, L., Vincent, E., Labeyrie, L.D., Rostek, F., Müller, P.J., Quidelleur, X., and Lancelot, Y., 1994. Coarse fraction fluctuations in pelagic carbonate sediments from the tropical Indian Ocean: a 1,500kyr record of carbonate dissolution. Paleoceanography, 9:579-600.

Berger, W.H., 1970. Biogenous deep-sea sediments: fractionation by deepsea circulation. Geol. Soc. Am. Bull., 81:1385-1401.

, 1973. Deep-sea carbonates: Pleistocene dissolution cycles. J. Foraminiferal Res. 3:187-195.

Berger, W.H., Adelseck, C.G., and Mayer, L.A., 1976. Distribution of carbonate in surface sediments of the Pacific Ocean. J. Geophys. Res. 81:2617-2627.

Berger, W.H., Bonneau, M.C., and Parker, F.L., 1982. Foraminifera on the deep-sea floor: lysocline and dissolution rate. Oceanol. Acta, 5:249-258.

Bickert, T., 1992. Rekonstruktion der spätquartären Bodenwasserzirkulation im östlichen Südatlantik über stabile Isotope benthischer Foraminiferen. Ber. FB Geo. Univ. Bremen, 27:1-205.

Bickert, T., Berger, W.H., and Wefer, G., in press. The deep western equatorial Pacific in Quaternary times: results from Leg 130 (Ontong Java Plateau). Paleoceanography.

Bickert, T., and Wefer, G., 1996. Late Quaternary deep-water circulation in the South Atlantic: reconstruction from carbonate dissolution and benthic stable isotopes. In Wefer, G., Berger, W. H., Siedler, G., and Webb, D. (Eds.), The South Atlantic: present and past circulation: Berlin (Springer-Verlag), 599-620.

Biscaye, P.E., Kolla, V., and Turekian, K.K., 1976. Distribution of calcium carbonate in surface sediments of the Atlantic Ocean. J. Geophys. Res., 81:2595-2603.

Boyle, E.A., 1988. Cadmium: chemical tracer of deepwater paleoceanography. Paleoceanography, 3:471-489.

Briggs, K.V., Richardson, M.D., and Young, D.K., 1985. Variability in geoacoustic and related properties of surface sediments from the Venezuela Basin, Caribbean Sea. Mar. Geol., 68:73-106.

Broecker, W.S., 1982. Ocean chemistry during glacial time. Geochim. Cosmochim. Acta, 46:1689-1705.

Broecker, W.S., and Peng, T.H., 1987. The role of $\mathrm{CaCO}_{3}$ compensation in the glacial to interglacial atmospheric $\mathrm{CO}_{2}$ change. Global Biogeochem. Cycles, 1:15-29.

, 1989. The cause of the glacial to interglacial atmospheric $\mathrm{CO}_{2}$ change: a polar alkalinity hypothesis. Global Biogeochem. Cycles, $3: 215-239$.

Crowley, T.J., 1983. Depth-dependent carbonate dissolution changes in the eastern North Atlantic during the last 170,000 years. Mar. Geol., 54:M25-M31.

, 1985. Late Quaternary carbonate dissolution changes in the North Atlantic and Atlantic/Pacific comparisons. In Sundquist, E., and Broecker, W.S. (Eds.), The carbon cycle and atmospheric $\mathrm{CO}_{2}$ : Natural variations, Archean to Present. Geophys. Momogr., Am. Geophys. Union, 32:271-284.

Curry, W.B., 1996. Late Quaternary deep circulation in the western equatorial Atlantic. In Wefer, G., Berger, W. H., Siedler, G., and Webb, D. (Eds.), The South Atlantic: present and past circulation: Berlin (Springer-Verlag), 577-598. 
Curry, W.B., Duplessy, J.C., Labeyrie, L.D., Shackleton, N.J., 1988. Changes in the distribution of $\delta^{13} \mathrm{C}$ of deep water $\Sigma \mathrm{CO}_{2}$ between the last glaciation and the Holocene. Paleoceanography, 3:317-341.

Curry, W.B., and Lohmann, G.P., 1990. Reconstructing past particle fluxes in the tropical Atlantic Ocean. Paleoceanography, 5:487-505.

Curry, W.B., Shackleton, N.J., Richter, C., et al., 1995. Proc. ODP, Init. Repts., 154: College Station, TX (Ocean Drilling Program).

Damuth, J.E., 1977. Late Quaternary sedimentation in the western equatorial Atlantic. Geol. Soc. Am. Bull., 88:695-710.

Damuth, J.E., and Kumar, N., 1975. Amazon Cone: morphology, sediments, age, and growth pattern. Geol. Soc. Am. Bull., 86:863-878.

Duplessy, J.C., Shackleton, N.J., Fairbanks, R.G., Labeyrie, L., Oppo, D., and Kallel, N., 1988. Deepwater source variations during the last climatic cycle and their impact on the global deepwater circulation. Paleoceanography, 3:343-360.

Emerson, S., and Bender, M., 1981. Carbon fluxes at the sediment-water interface of the deep-sea: calcium carbonate preservation. J. Mar. Res., $39: 139-162$.

Farrell, J.W., and Prell, W.L., 1989. Climatic change and $\mathrm{CaCO}_{3}$ preservation: an 800,000 year bathymetric reconstruction from the central equatorial Pacific Ocean. Paleoceanography, 4:447-466.

$\longrightarrow$, 1991. Pacific $\mathrm{CaCO}_{3}$ preservation and $\delta^{18} \mathrm{O}$ since 4 Ma: paleoceanographic and paleoclimatic implications. Paleoceanography, 6:485-498

Gardner, J.V., 1975. Late Pleistocene carbonate dissolution cycles in the eastern equatorial Atlantic. In Sliter, W.V., Bé, A.W.H., and Berger, W.H. (Eds.), Dissolution of Deep-Sea Carbonates. Spec. Publ. Cushman Found. Foraminiferal Res., 13:129-141.

Hebbeln, D., Wefer, G., and Berger, W.H., 1990. Pleistocene dissolution fluctuations from apparent depth of deposition in core ERDC-127P, westequatorial Pacific. Mar. Geol., 92:165-176.

Howard, W.R., and Prell, W.L., 1994. Late Quaternary $\mathrm{CaCO}_{3}$ production and preservation in the Southern Ocean: implications for oceanic and atmospheric carbon cycling. Paleoceanography, 9:453-482.

Imbrie, J., Boyle, E.A., Clemens, S.C., Duffy, A., Howard, W.R., Kukla, G., Kutzbach, J., Martinson, D.G., McIntyre, A., Mix, A.C., Molfino, B., Morley, J. J., Peterson, L.C., Pisias, N.G., Prell, W.L., Raymo, M.E., Shackleton, N.J.,Toggweiler, J.R., 1992. On the structure and origin of major glaciation cycles, 1. Linear responses to Milankovitch forcing. Paleoceanography, 7:701-738.

Jahnke, R.A., Craven, D.B., and Gaillard, J.F., 1994. The influence of organic matter diagenesis on $\mathrm{CaCO}_{3}$ dissolution at the deep-sea floor. Geochim. Cosmochim. Acta, 58:2799-2809.

Johnson, T.C., Hamilton, E.L., and Berger, W.H., 1977. Physical properties of calcareous ooze: control by dissolution at depth. Mar. Geol., 24:259277.

Keir, R.S., 1990. Reconstructing the ocean carbon system variation during the last 150,000 years according the Antarctic nutrient hypothesis. Paleoceanography, 5: 253-276.

Kolla, V., Bé, A.W.H., and Biscaye, P.E., 1976. Calcium carbonate distribution in the surface sediments of the Indian Ocean. J. Geophys. Res., $81: 2605-2616$

Le, J., and Shackleton, N.J., 1992. Carbonate dissolution fluctuations in the western equatorial Pacific during the late Quaternary. Paleoceanography, 7:21-42.

Mienert, J., and Bloemendal, J., 1989. A comparison of acoustic and rockmagnetic properties of equatorial Atlantic deep-sea sediments: paleoceanographic implications. Earth Planet. Sci. Lett., 94:291-300.

Moore, T.C., Pisias, N.G., and Dunn, D.A., 1982. Carbonate time series of the Quaternary and late Miocene sediments in the Pacific Ocean: a spectral comparison. Mar. Geol., 46:217-233.
Oppo, D.W., Fairbanks, R.G., Gordon, A.L., and Shackleton, N.J., 1990. Late Pleistocene Southern Ocean $\delta^{13} \mathrm{C}$ variability: North Atlantic deep water modulation of atmospheric $\mathrm{CO}_{2}$. Paleoceanography, 5:43-54.

Peterson, L.C., and Prell, W.L., 1985. Carbonate dissolution in Recent sediments of the eastern equatorial Indian Ocean: preservation patterns and carbonate loss above the lysocline. Mar. Geol., 64:259-290.

Raymo, M.E., Ruddiman, W.F., Shackleton, N.J., and Oppo, D.W., 1990. Evolution of Atlantic-Pacific $\delta^{13} \mathrm{C}$ gradients over the last $2.5 \mathrm{~m} . y$. Earth Planet. Sci. Lett., 97:353-368.

Reid, J.L., 1989. On the total geostrophic circulation of the South Atlantic Ocean: flow patterns, tracers, and transports. Progr. Oceanog., 23:149244.

Richey, J.E., Brock, J.T., Naiman, R.J., Wissmar, R.C., and Stallard, R.F., 1980. Organic carbon: Oxidation and transport in the Amazon River. Science, 207:1348-1351.

Ruddiman, W.F., and Janecek, T.R., 1989. Pliocene-Pleistocene biogenic and terrigenous fluxes at equatorial Atlantic Sites 662, 663, and 664. In Ruddiman, W., Sarnthein, M., et al., Proc. ODP, Sci. Results, 108: College Station, TX (Ocean Drilling Program), 211-240.

Rühlemann, C., Frank, M., Hale, W., Mangini, A., Mulitza, S., Müller, P.J., and Wefer, G., 1996. Late Quaternary productivity changes in the western equatorial Atlantic: evidence from ${ }^{230} \mathrm{Th}$-normalized carbonate and organic carbon accumulation rates. Mar. Geol.,135:127-152.

Sarnthein, M., Winn, K., Jung, S., Duplessy, J.-C., Labeyrie, L., Erlenkeuser, H., and Ganssen, G., 1994. Changes in east Atlantic deep-water circulation over the last 30,000 years: eight time slice reconstructions. Paleoceanography, 9:209-267.

Sundquist, E.T., and Broecker, W.S. (Eds.), 1985. The Carbon Cycle and Atmospheric $\mathrm{CO}_{2}$ : Natural Variations, Archean to Present: Geophys. Momogr., Am. Geophys. Union, 32.

Verardo, D.J., and McIntyre, A., 1994. Production and destruction: control of biogeneous sedimentation in the tropical Atlantic 0-300,000 years B.P. Paleoceanography, 9:63-86.

Vincent, E., 1981. Neogene carbonate stratigraphy of Hess Rise (central North Pacific) and paleoceanographic implications. In Thiede, J., Vallier, T.L., et al., Init. Repts. DSDP, 62: Washington (U.S. Govt. Printing Office), 571-606.

Volat, J.L., Pastouret, L., and Vergnaud-Grazzini, C., 1980. Dissolution and carbonate fluctuations in Pleistocene deep-sea cores: a review. Mar. Geol., 34:1-28.

Wu, G., Herguera, J.C., and Berger, W.H., 1990. Differential dissolution: modification of late Pleistocene oxygen isotope records in the western equatorial Pacific. Paleoceanography, 5:581-594.

Yasuda, M., Berger, W.H., Wu, G., Burke, S., and Schmidt, H., 1993. Foraminifer preservation record for the last million years: Site 805, Ontong Java Plateau. In Berger, W.H., Kroenke, L.W., Mayer, L.A., et al., Proc. ODP, Sci. Results, 130: College Station, TX (Ocean Drilling Program), 491-508.

Zahn, R., Rushdi, A., Pisias, N.G., Bornhold, B.D., Blaise, B., and Karlin, R., 1991. Carbonate deposition and benthic $\delta^{13} \mathrm{C}$ in the subarctic Pacific: implications for changes of the oceanic carbonate system during the past 750,000 years. Earth Planet. Sci. Lett., 103:116-132.

Date of initial receipt: 5 December 1995

Date of acceptance: 19 August 1996

Ms 154SR-109 